\title{
CORPORATE GOVERNANCE AND FORENSIC ACCOUNTANTS' ROLE: GLOBAL REGULATORY ACTION SCENARIO
}

\author{
Madan Lal Bhasin \\ Professor, Department of Accounting \& Finance, Bang College of Business, KIMEP University, \\ Almaty, Republic of Kazakhstan
}

\begin{abstract}
An increasing number of researchers are finding that 'poor' corporate governance $(C G)$ is a leading factor in poor performance, manipulated financial reports, and unhappy stakeholders. Corporations and regulatory bodies are now trying to analyse and correct any existing defects in their reporting system. In the current reporting environment, forensic accountants are in great demand for their accounting, auditing, legal, and investigative skills. Forensic accountants are positioned to explore the design of CG systems, the role of the financial reporting system in CG, the effect of the governance board on employee and managerial behaviour, and the efficacy of the internal control systems. As part of the governance committee, Forensic Accountants can make significant contributions in the area of $C G$, fraud prevention and investigation, creating positive work environment, establishing effective lines of communication and vigilant oversight. An attempt is also made here to portray global regulatory action scenario undertaken by leading bodies to prevent corporate frauds and improve $C G$ through accounting reforms. In nutshell, the Forensic Accountant is "a blood-hound of book-keeping."
\end{abstract}

Keywords: Corporate governance, forensic accounting, forensic accountant, global regulatory action scenario.

\section{INTRODUCTION}

Recently, forensic accounting (henceforth, FA) has come into limelight due to rapid increase in financial frauds and white-collar crimes. The integration of accounting, auditing and investigative skills creates the specialty, known as FA. In fact, FA is the 'specialty' practice area of accounting that describes engagements, which result from actual or anticipated disputes or litigation. 'Forensic' means "suitable for use in a court of law," and it is to that standard and potential outcome that forensic accountants generally have to work [1]. FA uses accounting, auditing, and investigative skills to conduct investigations, and thefts and frauds cases. No doubt, FA is listed among the top-20 careers of the future. The job of forensic accountants is to catch the perpetrators of the estimated $\$ 600$ billion theft and fraud occurring in the US companies every year. This includes tracing money laundering and identity theft activities, as well as, tax evasions [2]. 
Worldwide, we consider Sherlock Holmes to be the first forensic accountant [3]. However, the contribution of some historic characters in India cannot be ignored. In India, 'Kautilya' was the first person to mention the famous forty ways of embezzlement in his book 'Arthashastra' during the ancient times. He was the first economist, who openly recognized the need of the forensic accountants. Similarly, 'Birbal' was the scholar in the time of King Akbar. He used various tricks to investigate various types of crimes. Some of his stories gave the fraud examiner a brief idea about the Litmus test of investigation [4]. In the Egyptian times, 3300-3500 BC, commercial transactions were recorded on clay tablets, these tablets were then sealed, and if the tablets were found to be tampered with later, investigations took place [5]. Employee crime, when discovered was punishable by fine, mutilation or death in some cases. In India (321-184 BC) at least 40 different kinds of embezzlement were recorded and were punishable. The Roman Empire was concerned with administrative control. Emphasis was on control and audit of financial matters rather than efficiency of asset use. They experienced problems, such as, mismanagement of public monies, inflation and bankruptcies. The Romans relied on monetary and non-monetary data for such items as asset control. In the Middle-Ages, the rights of individuals were subsumed into those of a higher rank in society; the church was also an influence in matters of law, property and politics. The feudal system required rolls and estate accounts to be kept; they provided a base for both legal process and control. There was a formal alliance between law and accounting, The Royal Courts of Justice were responsible for both the accounting and administrative functions of central government.

The first official chartered accounting profession in 19th century at Scotland was based on and had strong linkages between accounting and law. In the 20th century, however, accounting services grew and legal consultancy became a smaller and smaller part of most accounting practices [2]. The emphasis was now on "record-keeping" and other financial services. Thus, FA appears to be a move towards the original role of accountants. Indeed, the 1960's saw the first legal case to highlight the role of FA to business and society. The 1980's saw a rapid expansion in demand for FA services, when many businesses suffered losses from the recession. The Association of Certified Fraud Examiners (ACFE) was established in Texas in 1988 and the American College of Forensic Examiners was founded in 1992. These were established because of recognition of the need for trained forensic accountants and to establish educational standards for their training. The sudden increase in the 1990's of white-collar crime, the complexity of technology and the September 11 terrorist attacks, which left many business facing financial ruin after losing almost all their accounting records has fuelled the demand for FA services. Undoubtedly, accountants have been involved in bringing life back into New York based businesses, after September 11, by compiling basic records so as to file insurance claims. They have also been involved in tracing the financing for the attacks - finding from where the terrorists got the money?

Over the past few years, these issues has been in the spotlight and accountants have been asked to question the 'traditional' view, i.e., accounting is about assessing whether financial statements meet Generally Accepted Accounting Practices (GAAP) as outlined by their professional bodies [6]. This has been shown, in some cases including Enron and WorldCom, to produce financial statements that may be enhanced to show a 'rosy' picture to investors [7]. Accountants, therefore, need to make sure that their interpretation of GAAP ensures "a true and honest representation of accounting data." Debates the world over about what is 'true and fair' according to GAAP continue and many professional bodies have chosen to adopt a more regulated approach including the USA. Many 
groups in society are expecting accountants to adopt a more active role in providing assurance regarding reliable financial reporting, responsible CG and detection and prevention of frauds [8]. Perhaps a forensic accountant may have been able to track these complex puzzles before the fallout from these events and highlighted them to investors. Thus, FA may be able to answer such questions as: can the reliability of auditors and the quality of the audit be believed? "It was a growing specialty before Enron, WorldCom and Sarbanes-Oxley. Now, it is really hot" [9].

In the USA, the Sarbanes-Oxley Act (SOA) of 2002 has forced top management to certify that financial statements are free of "fraud and material misstatement" [10]. This may mean that using an auditor may not be enough and the inclusion of a forensic accountant on the audit team may be required in the future. Increased fraud and illegal activity within corporations in the USA means increased pressure has been put on the auditor to meet the requirements of the Sarbanes-Oxley Act. Many accounting firms in the USA have expanded their services to include forensics and fraud. Recent corporate accounting scandals and the resultant outcry for transparency and honesty in reporting have given rise to two disparate yet logical outcomes. First, FA skills have become very crucial in untangling the complicated accounting maneuvers' that have obfuscated financial statements. Second, public demand for change and subsequent regulatory action has transformed CG scenario. Therefore, more and more company officers and directors are under ethical and legal scrutiny. In fact, both these trends have the common goal of addressing the investors' concerns about the transparent financial reporting system. The failure of the corporate communication structure has made the financial community realize that there is a great need for skilled professionals that can identify, expose, and prevent structural weaknesses in three key areas: poor CG, flawed internal controls, and fraudulent financial statements. FA skills, therefore, are becoming increasingly relied upon with a corporate reporting system that emphasizes its accountability and responsibility to stakeholders.

\section{LITERATURE REVIEW}

The literature on FA and its adoption in accounting and finance curriculum is rather limited and they are US centric. However, our objective in this section is to highlight the core findings in the few relevant current studies rather than an extensive examination of tangential issues to FA and its adoption in accounting and finance curriculum. Joshi [11] ascribed the origination of FA to "Kutilya," the first economist to openly recognize the need for the forensic accountant, whom he said, mentioned 40 ways of embezzlement centuries ago. He, however, stated that the term "forensic accounting was coined by Peloubet in 1946. Moreover, he defined FA as the application of specialized knowledge and specific skill to stumble up on the evidence of economic transactions.

Crumbley [1] wrote on same, when he stated that a form of FA can be traced back to an 1817 court decision. He stated that a "young Scottish accountant issued a circular advertising his expertise in arbitration support in 1824" but that Peloubet was probably the first to publish the phrase FA. Simply stated, FA (also called investigative accounting or fraud audit) is a merger of forensic science and accounting. Forensic science, according to Singleton [12] "may be defined as application of the laws of nature to the laws of man". He refers to forensic scientists as examiners and interpreters of evidence and facts in legal cases that also offers expert opinions regarding their findings in court of law. The science in question here is accounting science, meaning that the examination and interpretation will be of economic information. Investigation of fraud and corruption is confirmed, 
both in the developed and developing countries. It is only gaining prominence because of the growing wave of the crime under the seemingly new nomenclature during the last five years. Ozkul [13] defined FA as "the integration of accounting, auditing, and investigative skills." Simply put, FA is accounting that is suitable for legal review offering the highest-level of assurance and including the now generally accepted connotation of having been arrived at in a scientific fashion.

Gray [14] stated that FA involves the application of accounting concepts and techniques to legal problems. It demands reporting, where the accountability of the fraud is established and the report is considered as evidence in the court of law or in the administrative proceeding. It provides an accounting analysis that is suitable to the court, which will form the basis of discussion, debate and ultimately dispute resolution. This means that FA is a field of specialization that has to do with provision of information that is meant to be used as evidence especially for legal purposes. The persons practicing in this field (i.e., forensic accountants) investigate and document financial fraud and white-collar crimes, such as, embezzlement and investigate allegations of fraud, estimates losses damages and assets and analyses complex financial transaction. They provide those services for corporation, attorneys, criminal investigators and the Government. Their engagements are usually geared towards finding where money went, how it got there, and who was responsible. They are trained to look beyond the numbers and deal with business reality of the situation [15, 16]. Investigative and FA engagements are those that "require the application of professional accounting skills, investigative skills, and an investigative mindset; and involve disputes or anticipated disputes, or where there are risks, concerns or allegations of fraud or other illegal or unethical conduct Canadian Institute of Chartered Accountant, 2006).

FA is more than counting numbers; it involves solving complex financial puzzles, particularly in fraud, insurance, disputes, and providing legal evidence for presentation in a legal forum [17]. Activities include investigations of business information and data. These investigations can be to establish employee fraud, provide litigation support such as substantiation of insurance claims, analysis of facts, formulation of questions and examination of accounting systems and also business valuations. Wolosky adds accounting malpractice, legal malpractice, arson investigations and the tracing of assets to this list [9]. Techniques can include data reconstruction, data mining, horizontal analysis, vertical analysis, variance analysis, ratio analysis, cash flow analysis and comparison to other operating information including industry standards [18]. The accountant is already trained in many of the skills required for such tasks but needs some additional specialized skills to the skills of a traditionally trained accountant.

\section{POOR CORPORATE GOVERNANCE AND ACCOUNTING FAILURES}

Corporate governance (CG) first came into vogue in the 1970s in the United States. Within 25 years, CG had become the subject of debate worldwide by academics, regulators, executives and investors. The recent financial crisis has been a trigger for regulators, policy-makers, investors, and others to consider what improvements could be made to the corporate reporting system.

The corporate scandals (see Exhibit-1) of the last few years came as a shock not just because of the enormity of failures, but also because of the discovery that questionable accounting practice was far more insidious and widespread than previously envisioned. A definite link between these accounting failures and poor CG is beginning to emerge. Badawi [19] very aptly observes: "Adelphia, for 
example, was given a very low $24 \%$ rating by Institutional Shareholder Services on its CG score. In Europe, Parmalat and Royal Ahold were ranked in the bottom quartile of companies in the index provided by Governance Metrics International." Similarly, the Corporate Library had issued early failure warnings in respect of both WorldCom and Enron. An increasing number of researchers now are finding that poor CG is a leading factor in poor performance, manipulated financial reports, and unhappy stakeholders. Corporations and regulatory bodies are currently trying to analyze and correct any existing defects in their reporting system.

\subsection{Problems within the Corporate Governance and Reporting Systems}

The interests of investors and other stakeholders are usually protected by a three-tier security system. At the top-level is the company's "corporate governance code," which is directed toward enforcing company policies, achieving company objectives, monitoring company performance, and ensuring adequate disclosure of the company's activities. At the other end are the "reporting system," which is regulated by various public and private institutions, such as, the Securities and Exchange Commission (SEC), the Public Company Accounting Oversight Board (PCAOB), and Financial Accounting Standards Board (FASB), Securities and Exchange Board of India (SEBI), etc. These regulatory agencies require public companies to follow various accounting and disclosure standards, such as, Generally Accepted Accounting Principles (GAAP), and their auditors to audit as per Statement on Auditing Standards (SAS) like independence, ethical, and quality control standards. Linking the two extremes, however, is a company's "system of internal controls," which provides reasonable 'assurance' on the effectiveness and efficiency of operations, the 'reliability' of financial reporting, and 'compliance' with applicable laws and regulations. This system, however, seems to have been inadequate in many companies. As corporations scramble to realign their interests with those of their stakeholders, three main areas of weaknesses are emerging. They are summarized below.

\subsubsection{Lack of a well-developed and Implemented Policy of Corporate Governance}

The primary goal of CG is to enhance the value of a company through ethical behavior, espousing a policy of openness and fairness and ensuring informed decision-making throughout the company [20]. Unfortunately, the centre of corporate ethics (viz., board of directors) in certain cases became a magnet for unethical practices. Blinded by the glare of a rapidly growing stock market, pressured by stockholders for ever-increasing returns, and led by executives seeking to maximize bonuses based on stock performance, certain boards of directors and audit committees failed to constrain "creative" accounting to keep up their earnings numbers. It must have seemed to some directors that the investing public really did not care about issues (such as executive compensation) as long as they made their double-digit returns. The ratio of executive pay to that of the average worker ballooned to 600 to 1 in 2000, from 100 to 1 in 1990. Closed, entrenched boards magnified the problem as directors rewarded themselves for "quality" performance until, finally, the bubble burst.

\subsubsection{Lack of Honesty and Transparency in Reporting}

The financial reporting standards in the U.S. are the most "highly specified" in the world [1]. But falling stock markets, corporate failures, dubious accounting practices, abuses of corporate power, and criminal investigations indicate that the system is under stress. Some corporations have grown dramatically through acquisitions funded by inflated stock prices and promises of an even brighter future. In others, it seems as if the checks and balances that should protect shareholder interests were 
pushed to the side, driven by pursuit of the bottom line. It has traditionally been an auditor's responsibility to express an opinion on whether financial statements are presented according to GAAP. Contrary to the expectations of many in the public, the auditor does not have an absolute duty to uncover fraud, although Statement on Auditing Standard (SAS-99) prescribes steps for auditors to take in order to ensure that they have planned and implemented their audits in a way that responsibly addresses fraud considerations [21].

\subsubsection{An Inefficient and Ineffective System of Internal Control}

A good system of internal control will usually help a company to achieve its objectives of profitability and minimize loss of resources. Internal control cannot, however, change an inherently weak management system, or provide absolute assurance as to the reliability of financial reporting. Companies are now facing increasing levels of legal regulatory, and economic reporting requirements, because of the Sarbanes-Oxley Act of 2002 (SOA). Companies are spending millions of dollars examining their existing systems, and adopting or improving their $\mathrm{CG}$ and internal controls to meet the standards set by SOA sections 403 and 404 [22]. Undoubtedly, there will be lot of growth opportunities for various professionals to contribute to improve the corporate world. In today's rapidly changing business landscape, it is now necessary for accountants and companies to step away from the 'traditional' approach that emphasized mere compliance with the GAAP and the annual ritual involving check-box of items around legal requirements. Instead, they should focus on the study and investigation of the traits and follow the right spirit of various laws so as to improve performance, underlying corporate and management behavior in the long-term. This could be the key to preventing future meltdowns, and to guaranteeing the two important qualities of corporate reporting, namely, transparency and honesty.

\section{FORENSIC ACCOUNTING PROVIDES THE CONNECTING LINK}

Initially, forensic accountants were used by government agencies (such as, the CIA, the FBI, and the IRS), to uncover and investigate leading frauds. They became financial detectives; independent experts employed by management to uncover fraudulent financial reporting and misappropriated assets [20]. In the current reporting environment, forensic accountants are in great demand for their accounting, auditing, legal, and investigative skills. They can play a vital role in coordinating company efforts to achieve a cohesive policy of ethical behavior within an organization.

The definition of FA is changing in response to the growing needs of corporations. Bologna and Lindquist [23] had defined FA as "the application of financial skills, and an investigative mentality to unresolved issues, conducted within the context of rules of evidence. As an emerging discipline, it encompasses financial expertise, fraud knowledge, and a sound knowledge and understanding of business reality and the working of the legal system." According to the definition developed by the AICPA's Forensic and Litigation Services Committee [24], "forensic accounting may involve the application of special skills in accounting, auditing, finance, quantitative methods, the law, and research. It also requires investigative skills to collect, analyze, and evaluate financial evidence, as well as the ability to interpret and communicate findings. FA encompasses litigation support, investigation, and dispute resolution and, therefore, is the intersection between accounting, investigation and the law."

FA includes the use of accounting, auditing and investigative skills to assist in legal matters. 
According to Golden [25]: "It consists of two major components: litigation services that recognize the role of an accountant as an expert consultant, and investigative services that use a forensic accountant's skills and may require possible courtroom testimony." This implies that the forensic accountant should be skilled not only in financial accounting, but also in internal control systems, the law, other institutional requirements, investigative proficiency, and interpersonal skills. Corporations can rely on these skills for developing a consistent system of CG, disseminating such information within and outside the company, ensuring that governance policies and objectives are interwoven into the internal control system, setting up fraud prevention systems, and investigating any existing fraud.

\subsection{Core Knowledge and Personal Skills Required}

A forensic accountant is expected to be a 'specialist' in accounting and financial systems. Yet, as companies continue to grow in size and complexity, uncovering fraud requires a forensic accountant to become 'proficient' in an ever-increasing number of professional skills and competencies [26]. Here are some of the broad areas of useful expertise for a forensic accountant:

- An in-depth knowledge of financial statements and the ability to critically analyse them. These skills help forensic accountants to uncover abnormal patterns in accounting information and recognize their source.

- A thorough understanding of fraud schemes, including but not limited to asset misappropriations, money laundering, bribery, and corruption.

- The ability to comprehend the internal control systems of corporations, and to set up a control system that assesses risks, achieves management objectives, inform employees of their control responsibilities, and monitors the quality of the program so that corrections and changes can be made.

- Proficiency in computer and knowledge of network systems. These skills help forensic accountants to conduct investigations in the area of e-banking and computerized accounting systems.

- Knowledge of psychology in order to understand the impulses behind criminal behavior and to set up fraud prevention programs that motivate and encourage employees.

- Interpersonal and communication skills, which aid in disseminating information about the company's ethical policies and help forensic accountants to conduct interviews and obtain crucially needed information.

- Thorough knowledge of company's governance policies and the laws that regulate these policies.

- Command of criminal and civil law, as well as, of the legal system and court procedures.

With this background, the forensic accountant is distinctly positioned to explore the design of CG systems, the role of the financial reporting system in corporate governance, the effect of the governance board on employee and managerial behavior, and the efficacy of the internal control system.

So what personal skills are required to become a forensic accountant? In addition to the specialized knowledge about the techniques of finding out the frauds, one needs patience and analytical mindset [4]. One has to look beyond the numbers and grasp the substance of the situation. It is basically the work of the intelligent accountants. There is a need for the same basic accounting skills that it takes to become a good auditor plus the ability to pay attention to the smallest detail, analyze data 
thoroughly, think creatively, possess common business sense, be proficient with a computer, and have excellent communication skills. A "sixth" sense that can be used to reconstruct details of past accounting transactions is also beneficial. A photographic memory helps when trying to visualize and reconstruct these past events. The forensic accountant also needs the ability to maintain his composure when detailing these events on the witness stand. Finally, a forensic accountant should be insensitive to personal attacks on his professional credibility. A fraud accountant (forensic accountant are sometimes called) should also observe and listen carefully. By this, you can improve your ability to detect lies whether they involve fraud or not. This is so because "not all liars are fraudsters, but all fraudsters are liars" [27].

According to Mayur S. Joshi [28], India Forensic Consultancy Services (www.indiaforensic.com), "The traits of the forensic accountants could be compared to well-baked Pizza. The base of forensic accounting is accounting knowledge. Size and the extent of baking decide the quality of the Pizza. A middle layer is a dispersed knowledge of auditing, internal controls, risk assessment and fraud detection. It is like the spread of the cheese in Pizza. The toppings of this Pizza are a basic understanding of the legal environment. The legal environment is essential in order to support the litigations. The Cherry on the toppings of the Pizza is a strong set of communication skills, both written and oral. It is just the beautification part. Perfect combination of the Pizza base, Cheese spread and good toppings make the pizza delicious and the Forensic Auditor the perfect. It is a combination that will be in demand for as long as human nature exists."

In addition to these personal characteristics, accountants must meet several additional requirements to gain the position of forensic accountants, say a Certification, acknowledging his competence. One can learn forensic accounting by obtaining a diploma given by the Association of Certified Fraud Examiners (ACFE, see www.acfe.org) in the US. The Indian chapter of ACFE offers the course based on the white-collared crimes prevalent in US, based on their laws. However, it is most unfortunate that till now there is no formal body that provides formal education of the frauds in India. We can follow the good example shown by the Canada. The Canadian Institute of Chartered Accountants (CICA) had taken initiative in this direction and issued guidelines and pronouncements regarding investigative accounting [29]. Besides the formal certificate, one can deepen his knowledge and sharpen his skills in forensic accounting by undergoing training under experienced forensic accountant, participating in various international conferences, reading relevant journals, books and other literature on forensic accounting.

To combat the frauds effectively one needs the active support of government at every stage. There are three-four such agencies in India, which are dedicated to the mission of combating frauds. Serious Fraud Office looks into violations of Income Tax, FEMA, RBI Act, etc.; CBI (Economic Office Wing) deals with big financial frauds; Central Vigilance Commission deals with corruption are the major government agencies that combat frauds of different types. Unfortunately, there is no specialized education provided by any of the Universities in the country $[4,15]$. "Fraud Today" is the next generation of the fraud examinations in India. They plan to develop and market software, and develop resources for various world-class universities. Recently, TCS has also come out with software to combat money laundering and Subex Systems have designed software to combat the telecom frauds. Thus, combating the frauds with software has started picking up in India, with few big companies like ACL and IDEA, joining the race. 


\subsection{Forensic Accountant's Role in Improving CG}

Companies need a centralized program and an established system to measure and monitor internal controls effectiveness and the alignment between CG, internal control, and external reporting activities. Many are setting up "Governance Officers or Governance Committees" to meet the demand for corporate integrity. The governance committee must be active in every area of corporate activity to ensure that the company is operating as a synergistic whole. As part of the Governance Committee, a Forensic Accountant can make a significant contribution in each of the following areas:

- Corporate Governance: With a strong background knowledge of the legal and institutional requirements of $\mathrm{CG}$, a forensic accountant can help to formulate and establish a comprehensive governance policy that: ensures an appropriate mix of management and independent directors on the board; sets out the appropriate responsibilities of the board and the audit committees; has a fair allocation of power between owners, management, and the board; and ensures there is a company code of ethics for employees and management. Ethical behavior is reinforced when top management shows, through its own actions, that questionable behavior will not be tolerated.

- Preventing Fraud: Forensic accountants understand that the best way to prevent fraud is to establish an efficient control system that encompasses: a good control environment determined by management's philosophy of ethical behavior and strong CG policies; a superior accounting system that ensures the proper recording, classification, and reporting of all relevant transactions; and strong procedural controls that provide for safeguarding of assets, proper authorizations, audit mechanisms, and proper documentation.

- Creating a Positive Work Environment: A good fraud prevention program also accompanies a positive work environment where highly motivated employees are not tempted to abuse their responsibilities. Forensic accountants can ensure that CG policies are formulated to avoid high-risk environments where management is apathetic, pay is inadequate or too high, there is a serious lack of proper training and compliance, or there are unreasonable profit and budget goals. It is also necessary to have well-defined hiring policies that result in honest, well-qualified employees.

- Establishing Effective Lines of Communication: Communication is a key element in ensuring that employees and other stakeholders are aware of their rights and responsibilities. Committee of Sponsoring Organizations of the Treadway Commission (COSO) has very categorically stated: "Effective communication must flow not just from the top to lower levels, but also across employee lines of responsibility." Forensic accountants can, no doubt, support the dissemination of the required information about governance and ethics policies to interested parties within and outside the organization. Adequate reporting is also necessary to meet the compliance requirements of the SEC and the stock markets.

- Vigilant Oversight: Any system needs to be constantly monitored and evaluated to make sure that it is functioning well. A forensic accountant can monitor not only compliance at the top levels of corporate power, but also management procedures and employee activity. Information gathered as a result of the monitoring can be used to readjust and reformulate governance, ethics, and control policies.

- Establishing Consequences: Fraud deterrence should also include an expectation of punishment. The forensic accountant can help in creating policies that clearly state the company's intent to take action against any criminal activities, and that such action will apply 
to all levels of employees.

- Fraud Investigations: A forensic accountant can ensure the integrity of financial statements by actively investigating for fraud, identifying areas of risk and associated fraud symptoms, pursuing each anomaly aggressively, and delving into the minute's details of accounting and financial anomalies [30]. By helping companies to prevent and detect fraud, therefore, the forensic accountant's role can easily evolve into a key component in the CG system.

All of the larger accounting firms, as well as, many medium-sized and boutique firms have 'specialist' forensic accounting departments. Within these groups, there may be further subspecializations: some forensic accountants may, for example, just specialize in insurance claims, personal injury claims, fraud detection, construction, or royalty audits. Nearly 40 per cent of the top 100 US accounting firms are expanding their forensic and fraud services, according to Accounting Today. If this data is an indicator of Indian scenario, then the day is not far away when forensic accounting practice will contribute significantly to the total revenue of the Indian CA firms. In short, these services are in great demand and rendered at a premium in current context of flourishing business and rising instances of frauds and litigations.

\section{GLOBAL REGULATORY ACTION FOR CORPORATE FRAUDS, CORPORATE GOVERNANCE AND ACCOUNTING REFORMS SCENARIO}

The recent wave of corporate fraudulent financial reporting has prompted global actions for reforms in CG and financial reporting, by governments and accounting and auditing standard-setting bodies in the U.S. and internationally, including the European Commission (EC); the International Federation of Accountants (IFAC); the Organization for Economic Co-operation and Development (OECD); and others, in order to restore investor confidence in financial reporting, the accounting profession and global financial markets [31]. Major initiatives undertaken by some of the leading regulatory bodies are summarized below.

\subsection{The U. S. Sarbanes-Oxley Act of 2002}

The enactment of Sarbanes-Oxley Act (SOA) of 2002 was the U.S. government's quick-fix response to the wave of fraudulent corporate financial reporting experienced during the 1990s and early 2000s, and represented a significant step in regaining investors' confidence in the global financial reporting process [24]. In response to corporate and accounting scandals, the effects of which are still being felt throughout the U.S. economy, and in order to protect public interest and to restore investor confidence in the capital market, U.S. lawmakers passed the Sarbanes-Oxley Act of 2002. As Badawi and Fitzsimons [32] observes: "The Act resulted in major changes to compliance practices of large U.S. and non-U.S. companies whose securities are listed or traded on U.S. stock exchanges, requiring executives, boards of directors and external auditors to undertake measures to implement greater accountability, responsibility and transparency of financial reporting." The statutes of the Act and the new SEC initiatives (www.sec.gov) that followed are considered the most significant legislation and regulations affecting the corporate community and the accounting profession since 1993. Other U.S. regulatory bodies such as NYSE, NASDAQ and the State Societies of CPAs have also passed new regulations, which place additional burdens on publicly traded companies and their external auditors. External auditors of such registrants, regardless of their nationality or place of business, are subject to the oversight of the Public Company Accounting 
Oversight Board (visit PCAOB, at www.pcaobus.org) and to the statutory requirements of the SOA (available at www.aicpa.org).

The SOA created new and stricter statutes to avoid a repeat of previous corporate financial disasters. The Act not only applies to the U.S. entities but also covers primarily large non-U.S. companies whose securities are listed or traded on the U.S. stock exchanges, as well as their own non-U.S. external auditors, regardless of their nationality or place of business. Foreign entities are also complying with the provisions of the SOA from June 2005. The SOA resulted in major changes to compliance practices of large U.S. and non-U.S. companies (whose securities are listed or traded on U.S. stock exchanges) requiring executives, boards of directors and external auditors to undertake measures to implement greater accountability, responsibility and transparency of financial reporting. The statutes of the Act, and the new SEC initiatives that followed, are considered the most significant legislation and regulations affecting the corporate community and the accounting profession since 1933. Other regulatory bodies, such as the NYSE, NASDAQ and the State Societies of CPAs have also passed new regulations which place additional burden on publicly traded companies and their external auditors.

Although the SOA and the initiatives taken by the AICPA (SAS-99) are dramatic moves in attempting to reduce fraud, they alone may not be enough to solve the current problem [21]. A fundamental change in how accountants conduct audits is required. The extensive use of the evaluation of internal control in determining how an audit is conducted may have to be altered. In most cases, top management can override internal controls when involved in financial reporting fraud. Auditors are required to detect material misstatements of financial statements resulting from unintentional errors, fraud, and illegal acts [18]. Unfortunately, the majority of work carried on by auditors using the current system concentrates on the discovery of unintentional errors which, with an adequate system of internal control, will be detected by the company's accounting system." In addition, defalcations perpetrated by employees are in many cases immaterial. Therefore, financial reporting fraud that can result in the highest audit risk and can result in audit failures receives the least amount of attention. As Joseph Wells [27] stated, "I don't think an auditor could uncover fraud if he stepped on it." That is a poor assessment of the current audit system, but based on current events may be true.

Sarbanes-Oxley Act heightened the focus on fraud prevention and regulatory compliance in companies, fuelling the need for internal auditors and forensic accountants, among others. While the act is a source of "headaches" for many companies, it can be credited with creating unprecedented demand for chartered accountants, company secretaries and legal professionals. "The realignment of the rules required by the SOA created a great opportunity for CPAs across the globe," says Michael Badham, a partner at Deloitte \& Touche in Toronto. There are other factors. For example, corporate growth and the need to update information systems (combined with SOA) brought IT skills to the fore. And Canada's (along with India's) move to implement IFRS, slated for 2011, and is affecting all accountants, not just specialists. Moreover, trends that influence the U.S. markets also apply to India, Canada, the E.U., and several other countries. The United States' SOA has reverberated around the globe through the corporate and accounting reforms addressed by the International Federation of Accountants (IFAC); the Organization for Economic Cooperation and Development (OECD); the European Commission (EC); and authoritative bodies within individual European countries. 


\subsection{The International Federation of Accountants (IFAC)}

The IFAC (visit www.ifac.org) is a private governance organization whose members are the national professional associations of accountants. It formally describes itself as "the global representative of the accounting profession, with the objective of serving the public interest, strengthening the worldwide accountancy profession and contributing to the development of strong international economies by establishing and promoting adherence to high quality standards." The Federation represents accountancy groups worldwide and has served as a reminder that restoring public confidence in financial reporting and the accounting profession should be considered a global mission. It is also considered a key player in the global auditing arena, which, among other things, constructs international standards on auditing and has laid down an international ethical code for professional accountants [22]. The IFAC has recently secured a degree of support for its endeavors from some of the world's most influential international organizations in economic and financial spheres, including global Financial Stability Forum (FSF), the International Organization of Securities Commissions (IOSC), the World Bank and, most significantly, the European Commission (EC).

The IFAC commissioned a 'Task Force' on Rebuilding Public Confidence in Financial Reporting to use a global perspective to consider how to restore the credibility of financial reporting and corporate disclosure. Its report, "Rebuilding Public Confidence in Financial Reporting: An International Perspective," [33] includes recommendations for strengthening corporate governance, and raising the regulating standards of issuers. Some of its conclusions and recommendations [34] relating to audit committees is:

1. All public interest entities should have an independent audit committee or similar body.

2. The audit committee should regularly report to the board and should address concerns about financial information, internal controls or the audit.

3. The audit committee must meet regularly and have sufficient time to perform its role effectively.

4. Audit committees should have core responsibilities, including monitoring and reviewing the integrity of financial reporting, financial controls, the internal audit function, as well as for recommending, working with and monitoring the external auditors.

5. Audit committee members should be financially literate and a majority should have "substantial financial experience." They should receive further training as necessary on their responsibilities and on the company.

6. Audit committees should have regular private "executive sessions" with the outside auditors and the head of the internal audit department. These executive sessions should not include members of management. There should be similar meetings with the chief financial officer and other key financial executives, but without other members of management.

7. Audit committee members should be independent of management.

8. There should be a principles-based approach to defining independence on an international level. Companies should disclose committee members' credentials, remuneration and shareholdings.

9. Reinforcing the role of the audit committee should improve the relationship between the auditor and the company. The audit committee should recommend the hiring and firing of auditors and approve their fees, as well as review the audit plan.

10. The IFAC Code of Ethics should be the foundation for individual national independence rules. It should be relied on in making decisions on whether auditors should provide non-audit services. The audit committee should approve non-audit services performed by the auditor.

11. All fees, for audit and non-audit services, should be disclosed to shareholders.

12. Key audit team members, including the engagement and independent review partners, should 
serve no longer than seven years on the audit.

13. Two years should pass before a key audit team member can take a position at the company as a director or any other important management position.

\subsection{The Organization for Economic Co-operation and Development (OECD)}

The OECD (www.oecd.org) is a quasi-think tank made up of 30 member countries, including the United States and United Kingdom, and it has working relationships with more than 70 other countries. In 2004, the OECD unveiled the updated revision of its "Principles of Corporate Governance" [35] that had originally been adopted by its member governments (including the U.S. and U.K.) in 1999. Although they are non-binding, the principles provide a reference for national legislation and regulation, as well as guidance for stock exchanges, investors, corporations and other parties. The principles have long become an international benchmark for policy makers, investors, corporations and other stakeholders worldwide. They have advanced the corporate governance agenda and provided specific guidance for legislative and regulatory initiatives in both the OECD and non-OECD countries.

The 2004-updated version of "Principles of Corporate Governance" includes recommendations on accounting and auditing standards, the independence of board members and the need for boards to act in the interest of the company and the shareholders. The updated version [36] also sets more demanding standards in a number of areas that impact corporate executive compensation and finance, such as:

1. Granting investors the right to nominate company directors, as well as a more forceful role in electing them.

2. Providing shareholders with a voice in the compensation policy for board members and executives, and giving these stockholders the ability to submit questions to auditors.

3. Mandating that institutional investors disclose their overall voting policies and how they manage material conflicts of interest that may affect the way the investors' exercise key ownership functions, such as voting.

4. Identifying the need for effective protection of creditor rights and an efficient system for dealing with corporate insolvency.

5. Directing rating agencies, brokers and other providers of information that could influence investor decisions to disclose conflicts of interest, and how those conflicts are being managed.

6. Mandating board members to be more rigorous in disclosing related party transactions, and protecting so-called "whistle blowers" by providing the employees with confidential access to a board-level contact.

\subsection{The U.S. and E.U. Cooperation for Corporate Reforms}

Initially, the European Union resented applicability of U.S. Sarbanes-Oxley Act reforms to European companies and accounting firms operating in the U.S. However, after a series of negotiations, the U.S. and EU authorities have agreed to cooperate and decided to develop a compatible set of regulations. Gornik and McCarthy [31] have rightly pointed out as: "The regulatory bodies on both continents have undertaken a two-way cooperative approach based on effective equivalence of regulation and oversight authorities." Furthermore, member states of the European Union have proposed a code of conduct on the independent auditors, which includes a five-year auditor rotation requirement.

Furthermore, the national governments of the individual European countries have proposed reforms 
of their corporate laws. For example, in July 2002, the British government released a white paper proposing changes to the Company Law, which included harsher penalties for misleading auditors; redefining the roles of the directors; and creating standards for boards in accounting supervision and other disclosure issues. The British government is also reviewing the roles of non-executive directors and is considering the regulation of audit committees [36].

\subsection{Initiatives Taken in India}

There have been several leading CG initiatives launched in India since the mid-1990s. The first was by the Confederation of Indian Industry (CII), which came up with the first voluntary "Code of Corporate Governance" in 1998. The second was by the Securities and Exchange Board of India (SEBI), now enshrined as Clause 49 of the listing agreement. The Naresh Chandra Committee and Narayana Murthy Committee reports followed it in 2002. Based on some of their recommendations, SEBI revised Clause 49 of the listing agreement in August 2003. The Ministry of Corporate Affairs (MCA) (earlier Department of Company Affairs) had already set up "National Foundation for Corporate Governance" (visit www.nfcgindia.org) in partnership with CII, The Institute of Chartered Accountants of India (ICAI), and The Institute of Company Secretaries of India (ICSI). Recently, the MCA has set up a Serious Fraud Office under its jurisdiction to detect and prevent corporate frauds. In addition, the ICSI has constituted annual awards for the companies with best governance practices. To combat the frauds effectively and improve $\mathrm{CG}$, one needs the active support of the following Indian regulatory agencies at every stage: Serious Fraud Office looks into violations of Income Tax, FEMA, RBI Act, etc.; CBI (Economic Offence Wing) deals with big financial frauds; Central Vigilance Commission deals with corruption [20]. Unfortunately, there is no specialized education provided to fraud management, and improving CG by any of the leading Universities in the country. "Fraud Today" is the next generation of the fraud examinations in India. They plan to develop and market software, and develop resources for various world-class universities. Recently, TCS has also come out with software to combat money laundering and Subex Systems have designed software to combat the telecom frauds. Thus, combating the frauds with software has started picking up in India, with few big companies like ACL and IDEA, joining the race. Recently, the India Forensic Consultancy Services (www.indiaforensic.com), a private-sector body, has started offering certificate-level courses to Chartered Accountants, and bankers, so as to equip them with the detection and prevention of various types of frauds prevalent in India.

According to Panjwani [37], "Regulators are pushing listed companies to improve their CG practices through amendments to the Listing Agreement. A soon-to-be-announced new Companies Act will strengthen the basis for shareholder rights and the judicial system in India." The Ministry of Heavy Industries \& Public Enterprises issued (in June 2007) a new code for state enterprises, "Guidelines on Corporate Governance for Central Public Sector Enterprises (CPSEs)" [43]. While the code is voluntary, all CPSEs are expected to follow it and the ministry will "grade them on the basis of their compliance." Listed CPSEs must comply with these guidelines, in addition to fulfilling Clause 49 provisions. The government wants more CPSEs to enter the capital market, and it hopes that these guidelines will ensure that proper CG practices are in place to provide "appropriate public accountability".

It is a matter of great satisfaction that the ICAI Council agreed to fully converge with IFRS standards on or after April 1, 2011, citing the need to take up the matter of convergence with the government and other regulators (such as the RBI and SEBI) as well as train Indian professional accountants to 
effectively adopt and implement IFRS standards. Meanwhile, SEBI formed a committee on disclosures and accounting standards to advise on disclosure requirements for listed companies and to facilitate the implementation of accounting standards relating to capital markets. Thus, in CG practices, India can be proud of what it has achieved so far, initially voluntarily and later under guidance of various regulators, while recognizing that obviously much more needs to be done.

Recent events involving alleged misdeeds by corporate executives and independent auditors have damaged investor confidence in the financial markets. Despite intense efforts to stamp out corruption, misappropriation of assets, and fraudulent financial reporting, it appears that fraud in its various forms is a problem that is increasing in frequency and severity. KPMG's Fraud Survey [38] documented "a marked increase in overall fraud levels since its 1998 survey, with employee fraud by far the most common type of fraud. Further, it also noted that fraudulent financial reporting had more than doubled from 1998." This trend is consistent with the unprecedented recent spate of large accounting frauds, as well as, the increased number of accounting restatements and SEC enforcement actions in recent years. In response to the fraud problem, various regulatory authorities have enacted tougher laws and increased enforcement actions. Similarly, organizations are implementing tighter controls and broader oversight. The auditing professional has also adopted more rigorous auditing standards and procedures, and software developers are adding continuous monitoring features to back-office systems. Till date, it remains unclear whether these efforts are sufficient to mitigate the fraud problem and hence, the growing demand for forensic accounting all over the globe.

\section{Conclusion}

In the 21 st century, the corporate sector, all over the world, is facing rapidly increasing levels of regulatory and reporting requirements. They are forced to spend millions of dollars annually examining their existing systems and adopting/improving their CG and internal control systems to meet the standards set by the Sarbanes-Oxley Act of 2002. It is, therefore, necessary for the professionals (viz., the chartered accountants, company secretaries, auditors, legal and IT professionals) and companies to shift their focus from mere compliance approach to study and investigate the behavior of board of directors, CG practices, and financial reporting systems. There is no doubt that a qualified, trained and mature Chartered Accountants, possessing forensic accounting (FA) skills, can prove to be a valuable asset to the corporate-sector, and gradually help to improve their CG system [4]. Moves are afoot globally, both at the national and international levels, to promote convergence of CG practices. Let us hope, these moves could ensure in the long-term two important qualities of CG and reporting: transparency and honesty.

FA in India, of late, has come to limelight recently due to rapid increase in white-collar crimes and the belief that our law enforcement agencies do not have the expertise needed or time to uncover frauds. Forensic accounting, in fact, integrates accounting, auditing, and investigative skills to conduct an examination into a company's financial statements. Broad-based knowledge (within the themes listed above) is crucial to the success of entry-level forensic accountants. KPMG [38], a large accounting firm, believe the market is sufficiently large to support an independent unit devoted strictly to 'forensic' accounting. All of the larger accounting firms, as well as, many medium-sized and boutique firms have recently created forensic accounting departments. Because forensic accounting is relatively a new area of study, a series of working definitions and sharing of corporate 
experiences should be undertaken and encouraged to ensure a common understanding.

The recent wave of corporate fraudulent financial reporting has prompted global actions for reforms in CG and financial reporting, by governments and accounting and auditing standard-setting bodies in the U.S. and internationally. The enactment of Sarbanes-Oxley Act of 2002 was the U.S. government's response to the wave of fraudulent corporate financial reporting experienced during the 1980s and early 2000s, and represented a significant step in regaining investors' confidence in the global financial reporting process. The SOA created new and stricter statutes to avoid a repeat of previous corporate financial disasters. The Act not only applies to U.S. entities but also covers primarily large non-U.S. companies whose securities are listed or traded on U.S. stock exchanges, as well as their own non-U.S. external auditors, regardless of their nationality or place of business. Foreign entities have to comply with the SOA by June 2005.

Several global actions have been undertaken to respond to recent series of global corporate fraudulent financial reporting incidents and violation of the CG codes/norms, mostly in the U.S., Europe and other parts of the world. Across the Atlantic, the International Federation of Accountants (IFAC), Organization for Economic Co-operation and Development (OECD) and European Commission (EC) have recognized the recent eruption of corporate scandals in Europe and affirmed the inevitable need for CG reforms and regulation of the public accounting profession worldwide. The IFAC has passed the "Code of Professional Ethics" for international accounting firms. Similarly, the OECD has passed 'guidelines' for improving CG. Also, the European Union has proposed a 'code of conduct' for independent auditors, which include a five-year auditor rotation requirement. European countries are also involved in improving their corporate laws through governance codes of practice.

While the FA and auditing practice had commenced in the US as early as 1995, the seed of this specialization has yet to take off in India. The opportunities for the Forensic Accountants are growing at the rapid speed. Collapse of Enron and WTC "twin-towers" have blessed the American Forensic Accountants with the opportunities; they are only dealing with financial implications of the cases entrusted to them, and not engaging in auditing exercise. On account of global competition, the accounting profession must convince the marketplace that it has the "best-equipped" professionals to perform such services. I would like to recommend to the Council of ICAI to "consider incorporating FA and auditing and CG in their professional course curriculum." Finally, to all the CA's to consider FA and auditing as their "niche consulting" area of specialization.

\section{Exhibit-1: A Sample of Cases of Corporate Accounting Frauds}

Adelphia Communications: Founding family collected $\$ 3.1$ billion in off-balance-sheet loans backed by company. Earnings were overstated by capitalization of expenses and hiding debt.

AOL Time Warner: Barter deals and advertisements sold on behalf of others were recorded as revenue to keep its growth rate high. Sales were also boosted via "round-trip" deals with advertisers and suppliers.

Bristol-Myers Squibb: Inflated 2001 revenues by $\$ 1.5$ billion by "channel stuffing," forcing or giving inappropriate incentives to wholesalers to accept more inventory than they needed, to enable company to meet its 2001 sales targets.

CMS Energy: Executed "round-trip (buy and sell)" trades to artificially boost energy trading volume and revenues. 
Enron: Tops the list of biggest US corporate collapses. Company boosted profits and hid debts totaling over $\$ 1$ billion over several years by improperly using partnerships. It also manipulated the Texas power and California energy markets and bribed foreign governments to win contracts abroad. Qwest Communications: Inflated revenues using network capacity "swaps" and improper accounting for long-term deals. The SEC is investigating whether the company was aware of his actions, and possible improper use of company funds and related-party transactions, as well as improper merger accounting practices.

WorldCom: To cover losses, top executives overstated earnings by capitalizing $\$ 9$ billion of telecom operating expenses and thus overstating profits and assets over five quarters beginning 2001. Founder Bernard Ebbers' received $\$ 400$ million in off-the-books loans.

Xerox: Overstated earnings for five years, boosting income by $\$ 1.5$ billion, by misapplication of various accounting rules.

Parmalat (Itlay): Parmalat, a global food and dairy conglomerate, is Italy's eighth-largest company and the No. 3 provider of dairy (and cookie-maker) in the US. In Dec. 2003, a bank account with Bank of America holding 3.9 billion was revealed not to exist. More than 50 individuals were investigated. They were suspected of committing fraud and false financial accounting, which contributed to the company's bankruptcy. The company acknowledged a multi-billion-dollar gap in its balance sheet accounts. Parmalat's jailed founder estimated the size of deficiency in its finances at $\$ 10$ billion, and admitted that he shifted $\$ 620$ million from the company's coffers to unprofitable travel businesses that were controlled by his family.

Royal Dutch/Shell Group: Shell, the third largest oil company, is a global group of energy and petrochemical companies, operating in more than 145 countries. In July 2004, the company reported paying a total of $\$ 150$ million in fines to the SEC and its British counterpart, the Financial Services Authority, following investigations into the company's overstatement of its oil and gas reserves. Since Jan. 2004, the company was subject to intense criticism and scrutiny when executives made the first of four restatements related to its oil and gas reserves. Shell agreed with Britain's FSA's findings that it abused the provisions of the FSM Act. It paid 17 million pounds in fines, the largest the regulator has ever levied. Shell also agreed to an SEC order that finds that the company violated antifraud reporting, record-keeping and internal control provisions of US federal securities laws. The company also was investigated by the US Department of Justice and by Netherlands regulators.

Vivendi Universal (France): The SEC accused this Paris-based company of misleading investors in its news releases and financial statements. Management was engaged in misconduct trying to meet earnings goals and intentionally violated certain accounting principles to inflate profits. For 18 months, senior executives refused to acknowledge the company's liquidity problems and earnings shortfalls. Its former CEO transformed the company from a water utility into a film and media empire but saddled it with huge debts (33 billion), which were difficult to pay. On Dec. 23, 2003, the company agreed to pay $\$ 50$ million to settle accusations by the SEC and it did not have to revise any financial statements.

\section{REFERENCES}

[1] Crumbley, D.L., Heitger, L.E., and Smith, G.S. (2007), "Forensic and Investigative Accounting," Chicago: CCH Incorporated.

[2] Cheffins, B.R. (2012) “The History of Corporate Governance," ECGI Working Paper Series 
in Law, available at www.ssrn.com.

[3] Kahan, S. (2004). "Sherlock Holmes of Accounting," Accounting Today, Volume 18, No. 10, pp. 1-2.

[4] Bhasin, M.L. (2007), "Forensic Accounting: A New Paradigm for Niche Consulting," The Chartered Accountant, January, published by the ICAI, New Delhi, pp. 1000-1010.

[5] Nurse, D.B. (2002), "Silent Sleuths," The CA Magazine, Toronto, Volume 135, No. 5, pp. 20-

23.

[6] Lehman, C.R. and Okcabol, F. (2005), "Accounting for crime," Critical Perspectives in Accounting, Volume 16, (2005), pp. 613-639.

[7] Rezaee, Z. (2005). "Causes, Consequences and Deterrence of Financial Statement Fraud," Critical Perspectives in Accounting, Volume 16, pp. 277-298.

[8] Hassan, EZ and Morteza, R. (2012), "Accountant's Perception of Forensic Accounting," Global Journal of Management and Business Research, Volume 12, Issue 6, March, pp. 1-4.

[9] Wolosky, H.W. (2004), "Forensic Accounting to the Forefront," Practical Accountant, February, pp 23-28.

[10] Christensen, J.A., Byington, J.R. AND Blalock, T.J. (2005), "Sarbanes-Oxley: Will You Need a Forensic Accountant?", The Journal of Corporate Accounting \& Finance. March/April.

[11] Joshi, M.S. (2003), "Constable Hunt for Cooked Books," available at www.indiaforensic.com.

[12] Singleton, T.W., Singleton, A.J., Bologna, G.J. and Lindquist, R.J. (2006), "Fraud Auditing and Forensic Accounting," John Wiley \& Sons, Third edition.

[13] Ozkul, F.U. and Pamukcu, A. (2012), "Fraud Detection and Forensic Accounting," Emerging Fraud, Springer-Verlag Berlin Heidelberg, Volume 35, pp. 19-41.

[14] Gray, Dahli (2008), "Forensic Accounting and Auditing: Compared and Contrasted to traditional accounting and auditing," American Journal of business education, Fourth Quarter, Volume 1, No. 2, pp 115-126.

[15] Efiong, E.J. (2012), "Forensic Accounting Education: An Exploration of Level of Awareness in Developing Economies," International Journal of business and management, Volume 7, No. 4, February, pp. 26-34.

[16] Koh, A.N. and Suat, C.L.A. (2009), "Forensic Accounting: Public Acceptance towards Occurrence of Fraud Detection," International Journal of Business and Management, Volume 4, No. 11, November, pp. 145-149.

[17] Houk, M.M., Kranacher, M., Morris, B., Riley, R.A, Robertson, J. and Wells, J.T., (2006), "Forensic Accounting as an Investigative Tool," The CPA Journal, August, pp. 68-70.

[18] Latshaw, C.A. (2005), "Fraudulent Financial Reporting: The Government and Accounting Profession React," Review of Business, Spring, pp. 13-15.

[19] Badawi, I. and Fitzsimons, A. (2002), "Sarbanes-Oxley Act and SEC Proposals Address Corporate Responsibility," Bank Accounting \& Finance, Volume 5, No. 6, October .

[20] Bhasin, M.L. (2006), "Corporate Governance: Challenge of Increasing Transparency in the Asian Countries," The Chartered Secretary, March, published by the ICSI, New Delhi.

[21] Statement on Auditing Standards No. 99 (2002), "Consideration of Fraud in a Financial Statement Audit," Auditing Standards Board of the American Institute of Certified Public Accountants (AICPA) in October.

[22] Telberg, R. (2003), “Credibility Crisis Needs Global Curve," Al Large, August 11, available at www.cpa2bis.com.

[23] Bologna, G.J. and Lindquist (1995), "Fraud Auditing and Forensic Accounting: New Tools 
and Techniques," Wiley \& Sons,

[24] American Institute of Certified Public Accountants, "Summary of Sarbanes-Oxley Act 2002," available at http://www.aicpa.org/info/sarbanes_oxley_summary.html.

[25] Golden, Thomas W., Skalak, Steven L., and Clayton, Mona M., "A Guide to Forensic Accounting," John Wiley \& Sons, 2006.

[26] Silverton, H. and Sheetz, M., "Forensic Accounting and Fraud Examination for Nonexperts," Wiley \& Sons, Inc. 2008.

[27] Wells, J.T. "Build an Antifraud Practice," Journal of Accountancy, March 2004, pp. 48-51.

[28] Joshi, M.S. (2006), "What is Forensic Accounting?," pp. 1-3, available at www.indiaforensic.com.

[29] Rosen, L.S. (2007), "Forensic Accounting: Where and When Headed?" The Canadian Accounting Perspectives, CAP Volume 5, No. 2, pp. 257-264.

[30] Owojori, A.A. and Asaolu, T.O. (2009), "The Role of Forensic Accountant in Solving the Vexed Problem of Corporate World," European Journal of Scientific Research, Volume 29, No. 2, pp. 183-187.

[31] Gornik-Tomaszewski, S. and McCarthy, I. (2005), "Response to Corporate Fraud in the United States and Europe: Towards a Consistent Approach to Regulation," Review of Business, Volume 26, No.2, Spring.

[32] Badawi, I.M. and Fitzsimon, A.P. (2003), "Proposals and New Rules Address Auditors' and Management' Responsibilities for Financial Reporting and Disclosure," Bank Accounting \& Finance, Volume 16, No. 2, pp. 23-28.

[33] International Federation of Accountants (2005), "Rebuilding Public Confidence in Financial Reporting: An International Perspective," see www.aicpa.org/audcommctr/guidance.

[34] International Federation of Accountants (2002), "Auditors and Audit Committee" October 2002, available at www.aicpa.org.

[35] Organization for Economic Co-operation and Development (2004), "Principles of Corporate Governance," available at http://www.oecd.org.

[36] CFOEurope, "Where to Now?" October 2002, www.cfoeurope.com/2002 10e.html.

[36] Taub, S. (2004), "Scandals Prompt Global Action: The OECD Rewrites Draft," www.CFO.com, January 20.

[37] Panjwani, R. "India: Tightening the Scews," in CG Watch 2005, 2007 by the Asian CG Association, Hong Kong, pp. 60-69.

[38] KPMG: "The US Fraud Survey," New York, KPMG Peat Marwick. 